Bangladesh J. Bot. 42(1): 145-153, 2013 (June)

\title{
DETECTION OF METABOLITES OF BENZO(A)PYRENE IN SORBUS SIBIRICA HEDL. LEAVES AND THEIR USE IN THE ASSESSMENT OF AIR POLLUTION OF KEMEROVO CITY (RUSSIAN FEDERATION)
}

\author{
OA NeVerova*, AA BYKov ${ }^{1}$ and OM Legoshina \\ The Institute of Human Ecology SB RAS, 650065 Kemerovo, \\ Avenue Leningradsky, 10, Russian Federation
}

Key words: Air pollution, Woody plants, Dispersion modeling, Metabolites, Benzapyrene

\begin{abstract}
This article analyzes the ability of woody plants to metabolize benzapyrene and shows the assessment of the level of long-term air pollution in the city of Kemerovo by benzapirene from the industrial area with the help of modelling approach. Metabolites of benzo(a)pyrene - B(a)P-1,3-dione, 1-hydroxy-B(a)P and B(a)P7,8- dihydrodiol are identified in extracts of Sorbus sibirica Hedl. leaves. It is found that there is a close correlation between the sum of relative abundance of hydroxyl derivatives of benzapyrene $(\Sigma \mathrm{OH}-\mathrm{B}(\mathrm{a}) \mathrm{P})$ of $S$. sibirica leaves and air pollution by benzapirene (Q).
\end{abstract}

\section{Introduction}

Kemerovo is an industrial center of Kuzbass, West-Siberian region, Russia. Industrial area of the city is a powerful source of air pollution. It is situated on the border of Centralnij and Zavodskij districts, and close to the residential areas. Priority emissions of industrial areas are nitrogen oxides, sulfur dioxide, carbon monoxide, suspended substances and polyaromatic hydrocarbons including benzo(a)pyrene.

It is known that benzo(a)pyrene has carcinogenic effect. To develop measures to reduce the risk of cancer rates of the population there is a necessity to estimate the degree of air pollution by benzo(a)pyrene $(\mathrm{B}(\mathrm{a}) \mathrm{P})$ and the nature of its distribution on the territory of the city. The ability of plants to inactivate $\mathrm{B}(\mathrm{a}) \mathrm{P}$ and to remediate the environment has already been established (Salt et al.1998, Glass 1999, Korte et al. 2000). It is known that the process of neutralization of B(a)P in plants occurs via its oxidative degradation to oxy derivatives by enzymes, followed by rupture of the aromatic rings and the formation of organic acids (Harms 1975, Ugrehelidze 1976, Harms et al.1977, Durmishidze et al.1979, Devdariani and Kavtaradze 1979, Devdariani 1988, Sandermann 1994, Khatisashvili et al. 1997, Gordeziani et al. 1999, Kvesitadze et al.2005). Thus, the presence of metabolites $\mathrm{B}(\mathrm{a}) \mathrm{P}$ in the plants may be an indicator of the pollutant's presence in the atmosphere.

In relation to the above mentioned facts, the present concerns were: 1 - to assess the ability of woody plants to metabolize B(a)P, 2 - to assess the level of long-term air pollution by B(a)P in the city of Kemerovo from the industrial area with the help of modelling approach, 3 - to compare the results of the modelling of air pollution by $\mathrm{B}(\mathrm{a}) \mathrm{P}$ with the contain of $\mathrm{B}(\mathrm{a}) \mathrm{P}$ metabolites in woody plants.

\section{Materials and Methods}

Studies were conducted in the summer of 2010. Six observation sites (OS) were selected for the study which were located on the 'torch's track of emissions' spreading from the industrial area and in the prevailing southwest wind direction (Fig. 1, Table 1).

*Author for correspondence: <nev11@yandex.ru>. ${ }^{1}$ Institute of Computational Technologies SB RAS, 650025, Kemerovo, Rukavishnikova Street, 21, RAS. 
The object of the present research was middle-aged generative state of the plant Sorbus sibirica Hedl., which grew in the investigated observation sites (OS) and remoted from the industrial area at different distances. Trees with satisfactory living conditions were used for the investigation, five trees from each OS were used. Leaves were collected from the annual shoots from the middle part of the south side crown of the sample trees and fixed at a temperature of $105^{\circ} \mathrm{C}$ for $20 \mathrm{~min}$, followed by final drying at $60^{\circ} \mathrm{C}$.

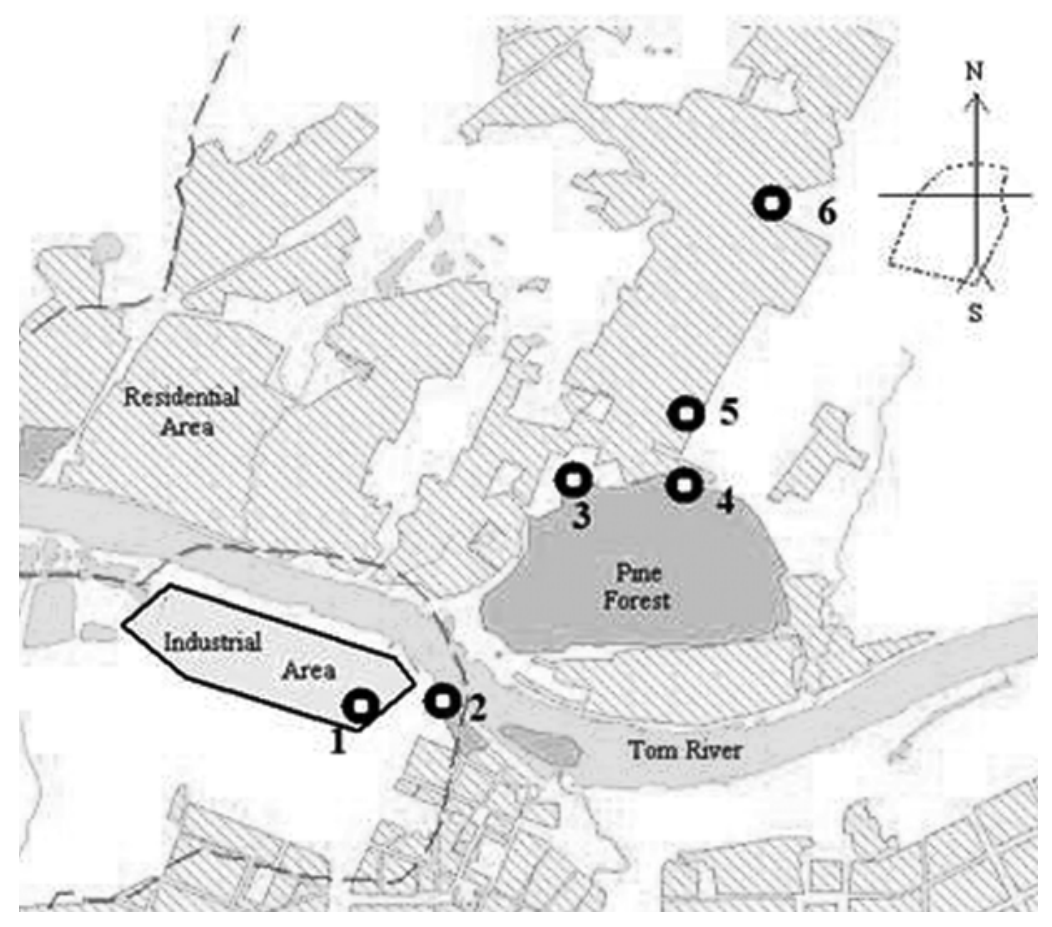

Fig. 1. Scheme of the observation sites (OS) on Kemerovo city plan.

Table 1. Description of the observation sites (OS).

\begin{tabular}{clc}
\hline OS & $\begin{array}{l}\text { Conventional site } \\
\text { description }\end{array}$ & $\begin{array}{c}\text { Distance to industrial } \\
\text { area }(\mathrm{km})\end{array}$ \\
\hline 1 & Park at the entrance of State District Power Plant (SDPP) & 0.1 \\
2 & Park n.a. Gorky & 0.6 \\
3 & Territory of the station of young naturalists & 3.0 \\
4 & Territory of the sanatorium "Zhuravlik" & 4.0 \\
5 & Miners park & 4.5 \\
6 & Yard of the rural hospital & 6.5 \\
\hline
\end{tabular}

To assess the ability of $S$. sibirica to metabolize B(a)P, the extracts of leaf metabolites of $\mathrm{B}(\mathrm{a}) \mathrm{P}$ were identified as: $\mathrm{B}(\mathrm{a}) \mathrm{P}-1,3-$ dione and mono- and dihydroxy derivatives - 1-hydroxy$\mathrm{B}(\mathrm{a}) \mathrm{P}$ and $\mathrm{B}(\mathrm{a}) \mathrm{P}-7,8$-dihydrodiol. These matabolites and their relative abundance were determined in the experimental laboratory of LLC "Spektronika" (Moscow) on the liquid chromatograph Dionex Ultimate 3000 with mass-spectrometer detector Applied Biosystems QTrap3200. 
The extracts of plant samples were prepared by solvent extraction method. For the detection of metabolites in extracts of B(a)P: B(a)P-1, 3-dione, 1-hydroxy-B(a)P and B(a)P-7,8-dihydrodiol it was decided to select $\mathrm{m} / \mathrm{z}$ corresponding to their protonated molecular ions. Selected ions were detected with a preliminary chromatographic separation of the extract and the chromatogram for selected ions was obtained.

The relative abundance of BP metabolites was determined by semiquantitative method. For this purpose mass chromatograms obtained with three MRM-transitions were calculated in the following way: for each metabolite was selected chromatogram of the extract with a maximum peak area of this metabolite and considering this area as $100 \%$ and calculated the content of this metabolite in other extracts, as a percentage of the peak area.

To estimate the average air pollution by $\mathrm{B}(\mathrm{a}) \mathrm{P}$ over a long period on investigated OS the atmospheric dispersion software system ERA was used. ERA was coordinated with the Main State Hydrometeorological Observatory n.a. A.I.Voeykova (St. Petersburg, Russia) for compliance with short-term model (OND-86, 1987) and long-term model (Supplement to the OND-86, 2005). Software system ERA is also used in Russia for regulatory calculations of air pollution (www.logos-plus.ru). At each receptor point the total average concentration is obtained by superposition of the concentrations of all individual sources.

The basic expression for calculation of the average concentration $\mathrm{C}\left(\mathrm{mg} / \mathrm{m}^{3}\right)$ over a long period at the point with polar coordinates relatively to the source has the following general form:

$$
C(r, \varphi)=\frac{p_{1}(\varphi) M}{r} \int_{0}^{\infty} d u \int_{0}^{\infty} d \lambda p_{2}(u) p_{3}(\lambda) q\left(r, u, \varphi, \lambda, H_{e}\right),
$$

where, $M(\mathrm{~g} / \mathrm{sec})$ - average emission rate of the source for the averaging time, and interpretation of symbols and formula for the integrand $q$ and the effective height of the source $H_{e}$ $(\mathrm{m})$ are presented in (Supplement to the OND-86, 2005); $p_{1}(\varphi)$ - function of wind direction; $p_{2}(u)$ - probability density of wind speed; $p_{3}(\lambda)$ - probability density of dimensionless parameter $\lambda$ that describes the intensity of turbulent mixing.

For the regulatory calculations $p_{2}(u)$ and $p_{3}(\lambda)$, which determine the regime of long-term air pollution in the vicinity of the source, are requested along with other necessary weather parameters in the Main State Hydrometeorological Observatory n.a. A.I.Voeykova. The function $p_{1}(\varphi)$ is obtained from the standard 8-wind rose by interpolation, the form of which is defined in (Supplement to the OND-86, 2005).

For this work, the constructed functions were $p_{1}(\varphi)$ and $p_{2}(u)$ for summer period of 2010. The data of standard meteorological observations of Kemerovo meteorological station were taken from the site www.rp5.ru. 8-wind rose, its relevant smoothed function $p_{1}(\varphi)$ and the function $p_{2}(u)$ are presented in Fig. 2.

Data on sources of pollution of Kemerovo city by B(a)P are taken from the cumulated volume of Kemerovo MPE (Azhiganich et al. 2003).

During the process of modeling the dimensionless concentration of $\mathrm{B}(\mathrm{a}) \mathrm{P}$ in the vegetation sampling points during the summer of $2010(\mathrm{Cr})$ and conditional variable $(\mathrm{Q})$ were calculated:

$C r=C / M P C d$, where $C$ are calculated in the sampling points by the formula (1). $M P C d=$ $0.000001 \mathrm{mg} / \mathrm{m}^{3}$ - the average daily maximum permissible concentration for $\mathrm{B}(\mathrm{a}) \mathrm{P}$ adopted in Russia. $\mathrm{Q}=780 \mathrm{Cr}$, where the factor 780 is selected to provide further clearness of comparison scheme of pollution with the rates of metabolites of benzo(a)pyrene in plants. 

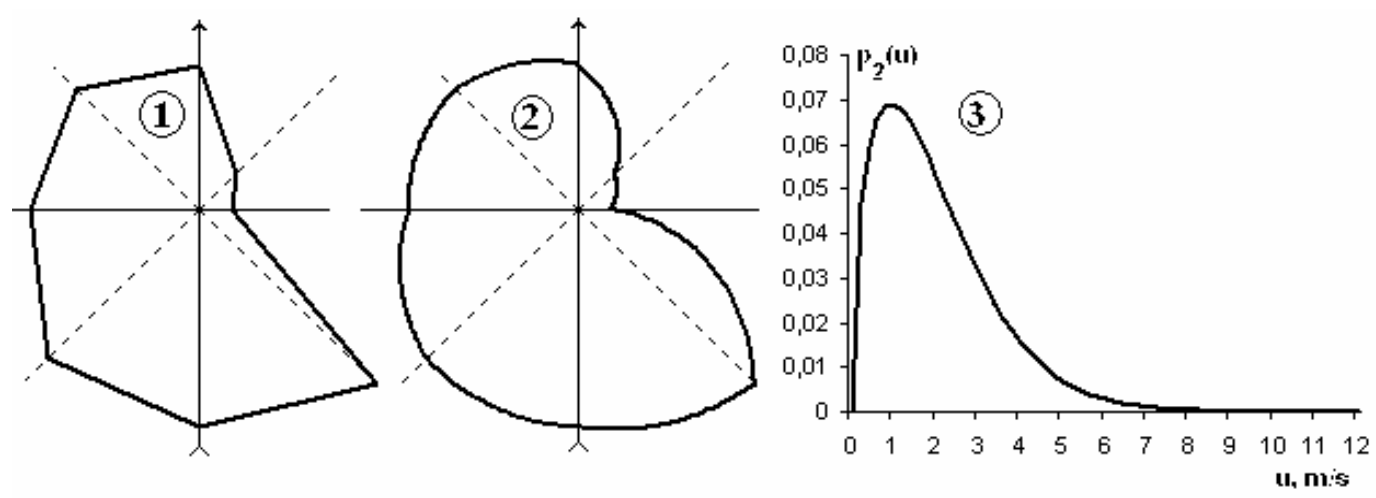

Fig. 2. Wind rose (1) and functions $p_{1}(\varphi)(2)$ and $p_{2}(u)$ (3) for summer period of 2010.

\section{Results and Discussion}

Mass spectrums of B(a)P metabolites are presented in Figs 3 - 6. In Fig. 3 mass chromatogram is presented, it is recordered in the mode of the selected ions, which were presented by the protonated metabolites of benzapyrene. Metabolites of BP are less hydrophobic than BP itself, they elute at a lower concentration of acetonitrile and come out of the column earlier, which can be seen at the chromatogram.

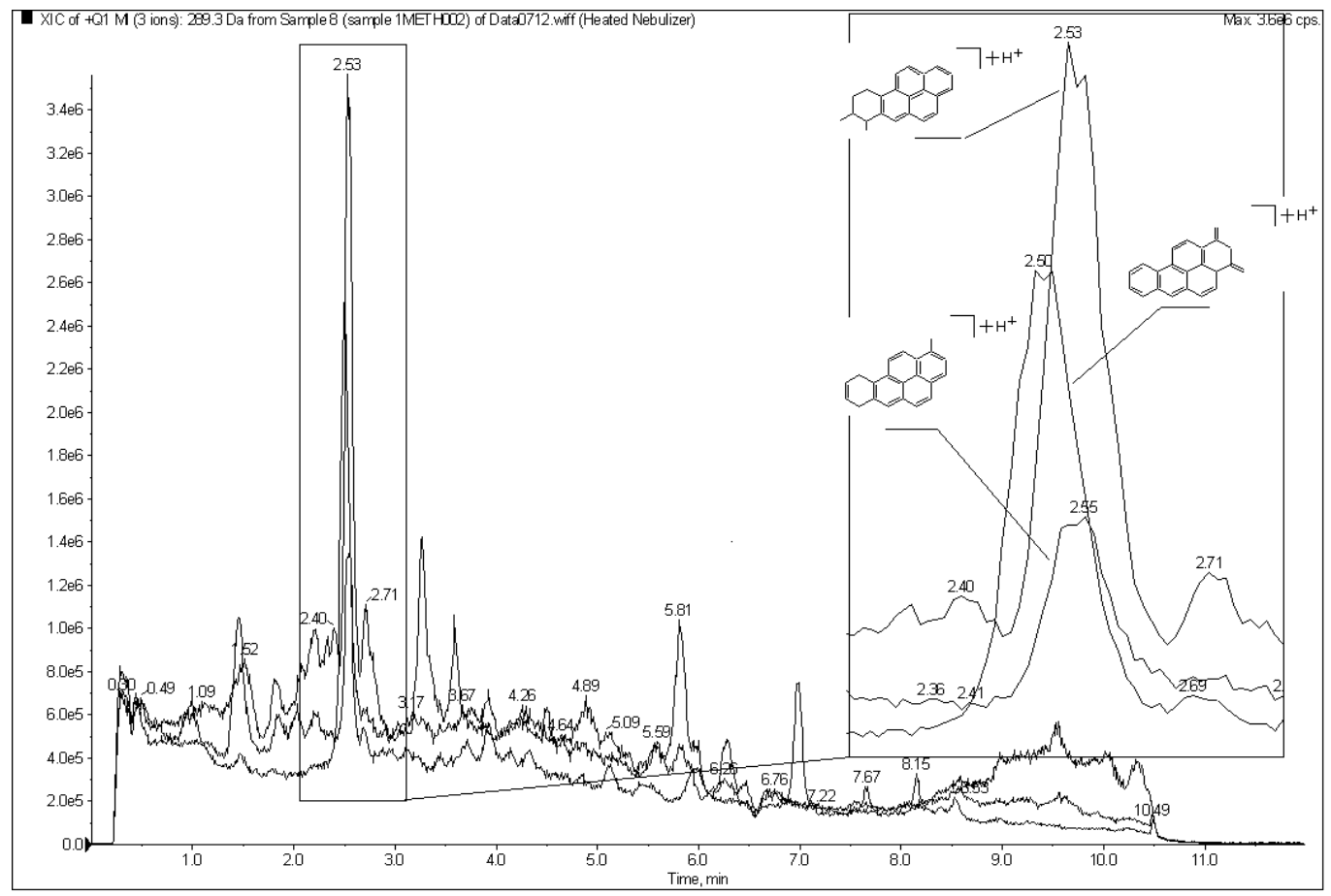

Fig. 3. Mass chromatogram of protonated metabolites of BP. 
To carry out quantitative studies for each metabolite MRM transitions were selected (masses of daughter ions which are well replicable and allow to identify each component selectively). For this purpose mass-spectrometer detection was conducted after chromatographic separation in $\mathrm{MS}^{2}$ mode. $\mathrm{MS}^{2}$ data were used to confirm the structure of metabolites and their correct interpretation. Mass spectrums $\mathrm{MS}^{2}$ of the three identified metabolites are presented in Figs 4 - 6 .

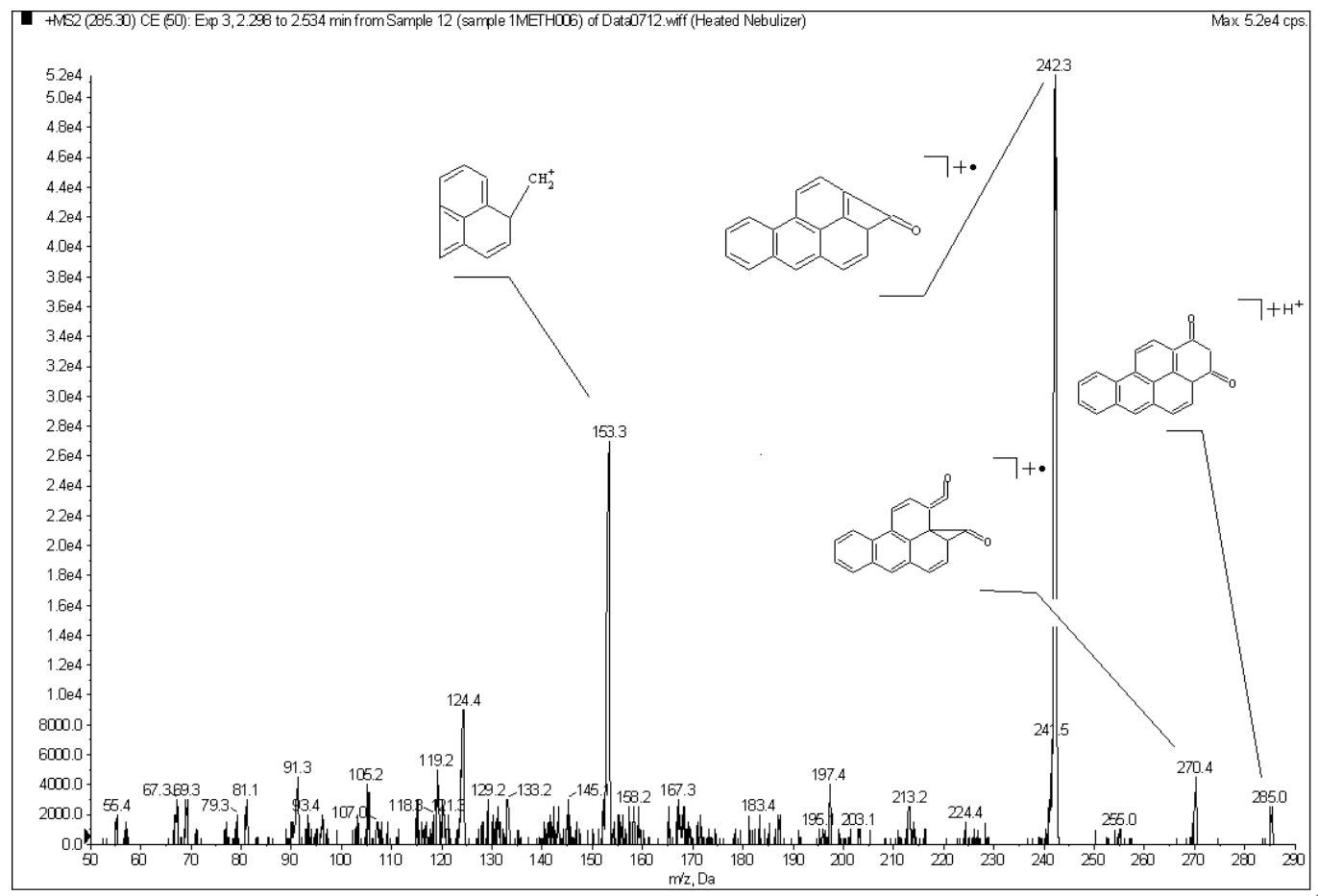

Fig. 4. Mass spectrum B(a)P -1,3-dione.

Protoned molecular ion 285 and ion 242 which has been taken as a daughter ion for MRM $285 / 242$ are clearly seen at mass spectrum.

With the use of MRM-transitions for each of the derivatives mass chromatograms providing a better selectivity (signal-to-noise ratio) than for the MS mode (single-quadrupole) were obtained.

The results of the study show that in extracts of Siberian mountain ash in the area of the Kemerovo industrial enterprises emissions the following metabolites of benzo(a)pyrene were found: B(a)P-1,3-dione and mono- and dihydroxy derivatives of benzo(a)pyrene - 1 -hydroxy$\mathrm{B}(\mathrm{a}) \mathrm{P}$ and $\mathrm{B}(\mathrm{a}) \mathrm{P}-7,8$-dihydrodiol.

In the literary sources it is reported that in plants the products of deep oxidation of benzapyrene are quinones and mono- and dihydroxy derivatives (Durmishidze et al. 1979, Devdariani et al. 1979, Devdariani 1988, Sandermann 1994). In particular, Durmishidze et al. (1979a) identified 6-hydroxy-B(a)P, B(a)P-1,6-dione, B(a)P-3,6-dione, and B(a)P-6,12-dione in plants. Kiselev (2008) and co-workers have reported about such benzapyrene metabolites, found in plants, as 3-hydroxy-B(a)P and 9-hydroxy B(a)P, B(a)P-7,8-dihydrodiol, B(a)P-9,10-dihydrodiol, B(a)P-4,5-dihydrodiol. 
Besides the protonated molecular ion, ion 271, indicating loss of water in the fragmentation of the parent ion is also clearly visible at the mass spectrum.

Present authors did not found any information about metabolites that had been found - B(a)P1,3-dione and 1-hydroxy-B(a)P, in the literary sources. The results of their study supplement information for possible ways of benzo(a)pyrene metabolisation by plants.

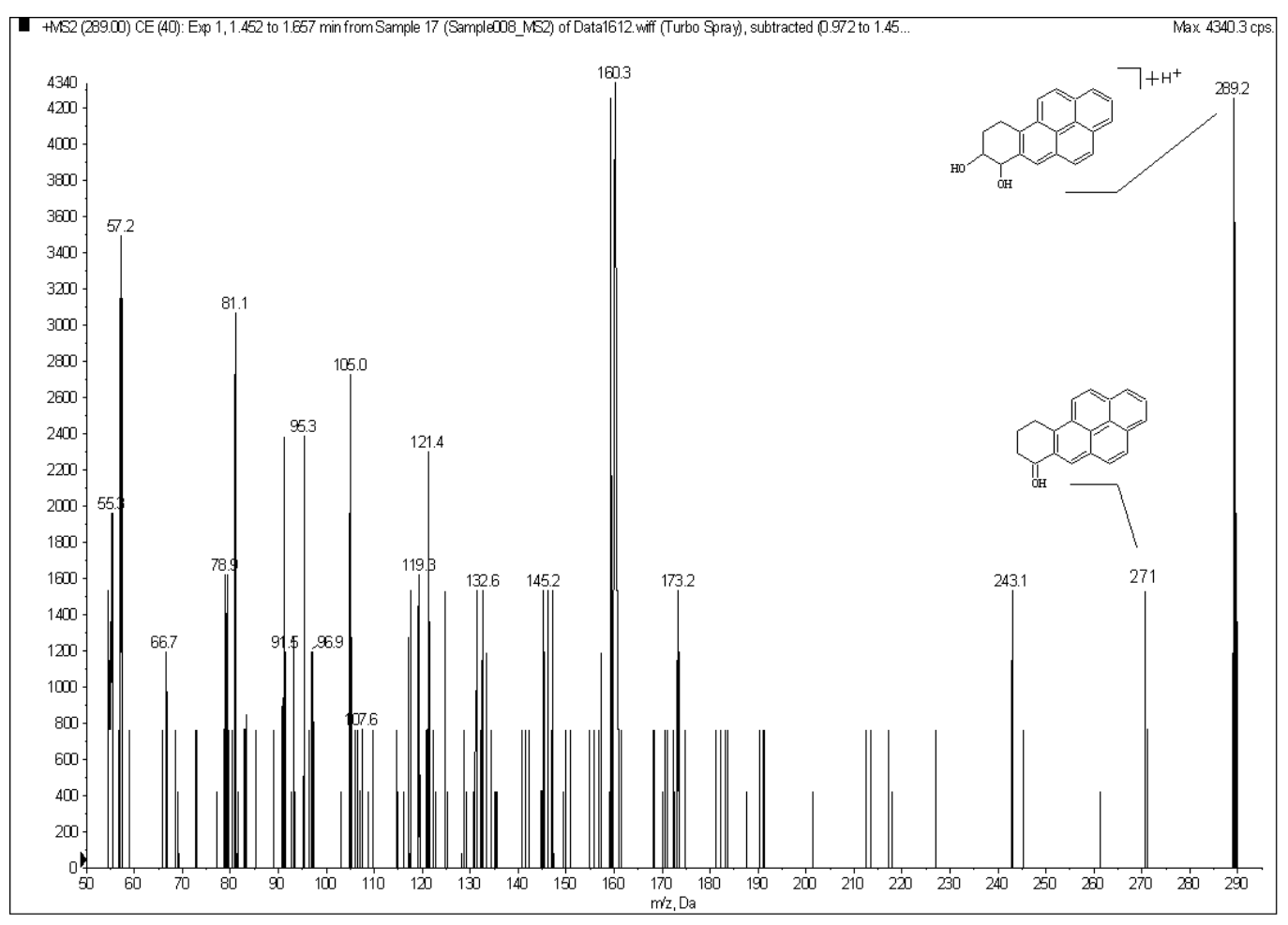

Fig. 5. Mass spectrum of benzapyrene-7,8-dihydrodiol.

It was established experimentally that, depending on the distance to the industrial area qualitative and quantitative differences exist in the content of $\mathrm{B}(\mathrm{a}) \mathrm{P}$ metabolites in the extracts of mountain ash. Thus on OS1 (very close to the industrial area) only $\mathrm{B}(\mathrm{a}) \mathrm{P}-1,3$ dion out of three investigated $\mathrm{B}(\mathrm{a}) \mathrm{P}$ metabolites was found in the mountain ash. Its relative amount is $55 \%$. Monoand dihydroxy derivatives of benzo(a)pyrene - B(a)P-7,8-dihydrodiol and 1-hydroxy-B(a)P were identified in the leaves of mountain ash, growing at a remote distance from the industrial area (OS 2-6). Moreover, in the mountain ash, growing on OS 2 and 4 the content of 1-hydroxy-B(a)P predominates (100 and 84\%, respectively), and on OS 3 and 5 - B(a)P-7,8-dihydrodiol predominates ( 88 and $100 \%$, respectively). The minimum content of $\mathrm{B}(\mathrm{a}) \mathrm{P}$ hydroxy derivatives in mountain ash is found on OS 6 (outermost from the industrial area). The content of B(a)P-7,8dihydrodiol is $28 \%, 1-$ hydroxy- $\mathrm{B}(\mathrm{a}) \mathrm{P}-37 \%$. These data indicate varying intensity of metabolic processes in the mountain ash, depending on the distance and level of OS contamination by benzo(a)pyrene.

The results of modeling of air pollution by $\mathrm{B}(\mathrm{a}) \mathrm{P}$ on investigated $\mathrm{OS}$ are presented in the Table 2. 
Table 2. Calculated rates of the average air pollution by $B(a) P$ on the investigated OS during the summer period of 2010

\begin{tabular}{lcccccc}
\hline Calculated rates & \multicolumn{7}{c}{ Investigated OS } \\
\cline { 2 - 6 } & 1 & 2 & 3 & 4 & 5 & 6 \\
\hline $\mathrm{Cr}=\mathrm{C} / \mathrm{MPCd}$ & 0.1485 & 0.1508 & 0.1740 & 0.1649 & 0.1760 & 0.1384 \\
$\mathrm{Q}=780 \mathrm{Cr}$ & 116.0 & 117.6 & 135.7 & 128.5 & 137.1 & 108.0 \\
\hline
\end{tabular}

The results testifies that air pollution by $\mathrm{B}(\mathrm{a}) \mathrm{P}$ is nonlinear while receding from the industrial area. In particular, on OS 5 content of $\mathrm{B}(\mathrm{a}) \mathrm{P}$ in the air is higher than near the industrial area (OS 1). This fact is explained by the influence of additional sources of $\mathrm{B}(\mathrm{a}) \mathrm{P}$ emissions, for example, heating stoves of private buildings, located in the area of OS 3,4 and 5, which use coal as fuel. However, the minimum values of $\mathrm{B}(\mathrm{a}) \mathrm{P}$ in the air are marked on the outermost OS 6 .

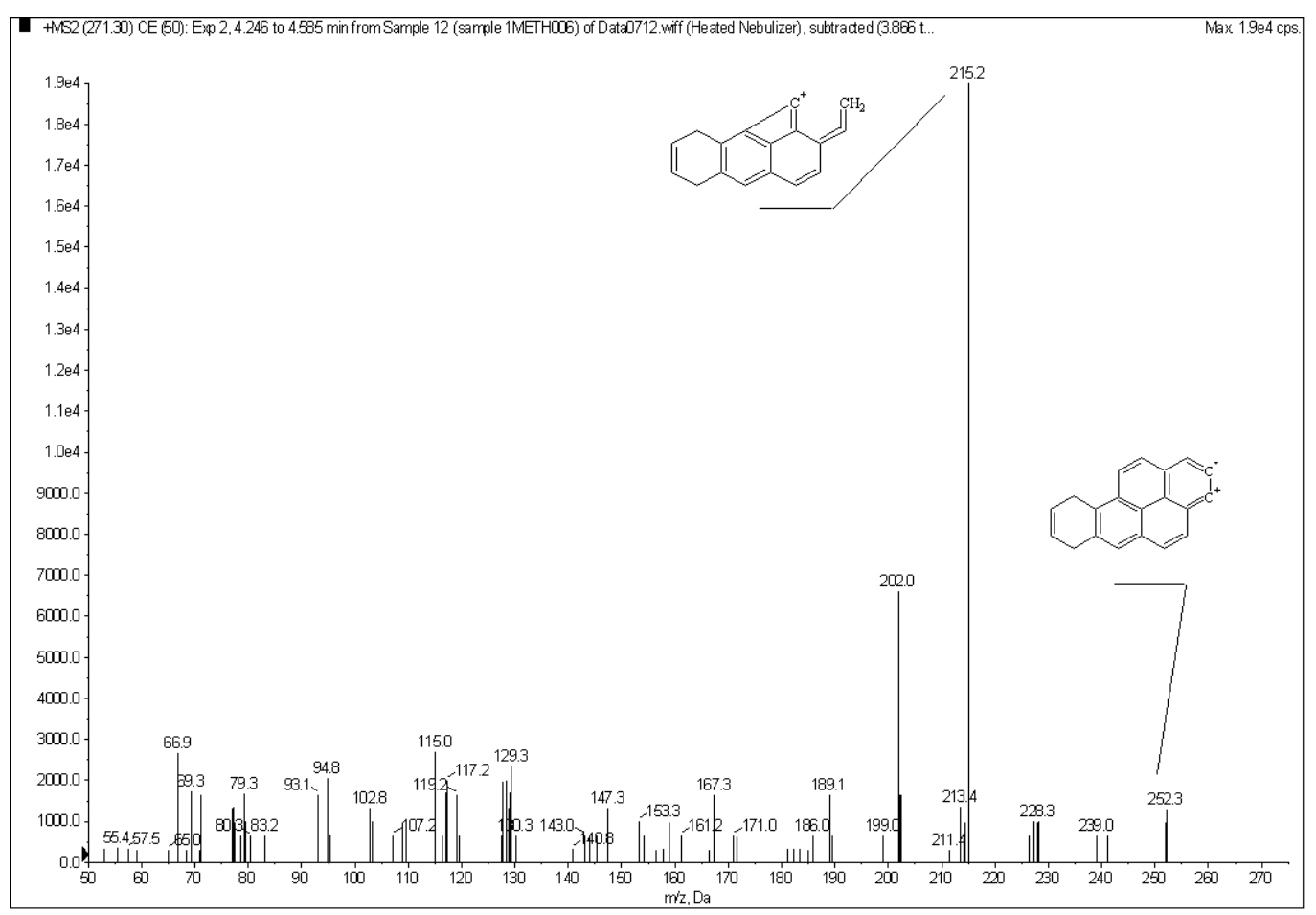

Fig. 6. Mass spectrum of 1-hydroxy-benzo(a)pyrene.

To assess the possibility of indication of air pollution by B(a)P in Kemerovo city, the present authors compared the indicators of the sum of relative abundance of B(a)P hydroxy derivatives $(\Sigma$ $\mathrm{OH}-\mathrm{B}(\mathrm{a}) \mathrm{P}$ ) with a condition variable Q (Fig. 7). The results show high convergence of compared rates on the investigated OS, confirmed by correlation analysis $(r=0.5$ for $n=75, p<0.05)$. It gives grounds to conclude that there is a possibility of using hydroxy derivatives of $\mathrm{B}(\mathrm{a}) \mathrm{P}$, found in plants for the indication of air pollution by $\mathrm{B}(\mathrm{a}) \mathrm{P}$. 
Such metabolites of benzo(a)pyrene, as B(a)P-1,3-dione and 1-hydroxy-B(a)P, B(a)P-7,8dihydrodiol were found in extracts of $S$. sibirica leaves, growing in the area of industrial emissions of Kemerovo city with the help of gas-liquid chromatography method. Obtained data supplement the information about the possible ways of metabolisation of benzo(a)pyrene by plants.

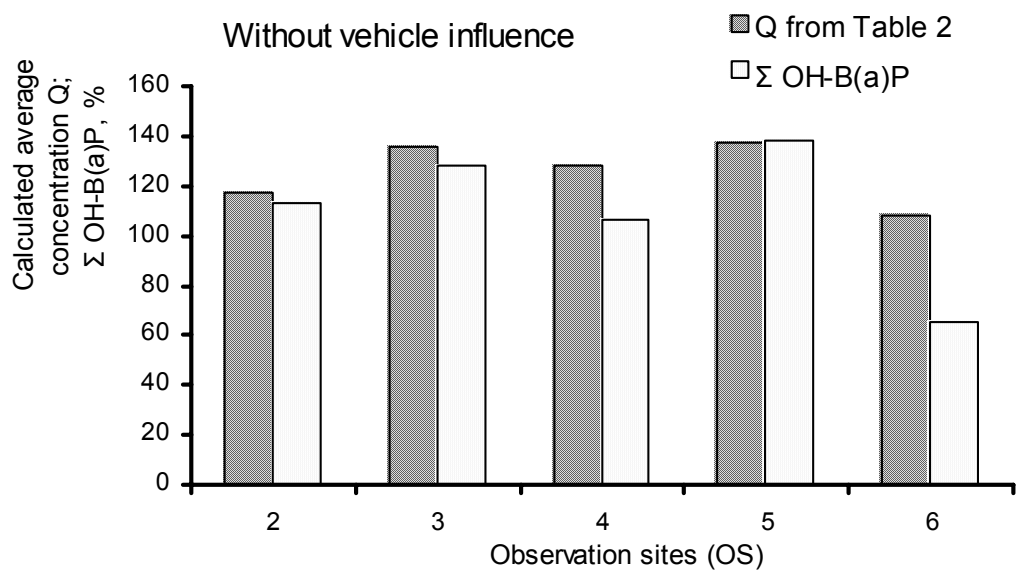

Fig. 7. Comparison of the calculated average concentrations of $\mathrm{B}(\mathrm{a}) \mathrm{P}(\mathrm{Q})$ with the sum of relative abundance of mono- and dihydroxy derivatives of $\mathrm{B}(\mathrm{a}) \mathrm{P}(\Sigma \mathrm{OH}-\mathrm{B}(\mathrm{a}) \mathrm{P})$ in the leaves of Sorbus sibirica.

Qualitative and quantitative differences are found in the content of $\mathrm{B}(\mathrm{a}) \mathrm{P}$ metabolites in extracts of S. sibirica depending on the distance from the industrial area. In close proximity to the industrial area (OS1) only B(a)P-1,3dion out the three investigated $\mathrm{B}(\mathrm{a}) \mathrm{P}$ metabolites was found (relative abundance 55\%) in extracts. Mono- and dihydroxy derivatives of benzo(a)pyrene $\mathrm{B}(\mathrm{a}) \mathrm{P}-7,8$-dihydrodiol and 1-hydroxy-B(a)P were identified in the leaves of mountain ash, growing at a remote distance from the industrial area (OS 2-6). Moreover, in the trees, growing on OS 2 and 4 the content of 1-hydroxy-B(a)P predominates, and on OS 3 and 5 - B(a)P-7,8dihydrodiol predominates. The minimum content of $\mathrm{B}(\mathrm{a}) \mathrm{P}$ hydroxy derivatives in trees is found on OS 6 (outermost from the industrial area). These data indicate varying intensity of metabolic processes in $S$. sibirica depending on the distance and level of OS contamination by benzo(a)pyrene.

Modelling approch shows that air pollution of Kemerovo city by $\mathrm{B}(\mathrm{a}) \mathrm{P}$ is nonlinear while receding from the industrial zone. This fact testifies the influence of additional sources of $\mathrm{B}(\mathrm{a}) \mathrm{P}$ emission close to the observation sites, at a distance from the industrial area. Such sources can be presented by heating stoves of private buildings, which use coal as fuel.

Close correlation is found between the sum of relative abundance of B(a)P hydroxy derivatives $(\Sigma \mathrm{OH}-\mathrm{B}(\mathrm{a}) \mathrm{P})$ of $S$. sibirica leaves with a conditional variable of air pollution by $\mathrm{B}(\mathrm{a}) \mathrm{P}$ $(Q)$. It prooves the possibility of using $\Sigma \mathrm{OH}-\mathrm{B}(\mathrm{a}) \mathrm{P}$ of $S$. sibirica leaves for the indication of air pollution by $\mathrm{B}(\mathrm{a}) \mathrm{P}$.

\section{References}

Azhiganich TE, Alekseychenko TG and Bykov AA 2003. Conduction of summary calculations of air pollution in Kemerovo for the regulation of emissions and diagnostic evaluations. In: Ecology of the city. Problems. Decisions"- City Scientific Conference V. - Kemerovo, 2003: 41-45. 
Devdariani TV and Kavtaradze LK 1979. The study of absorption and conversion of benzo(a)anthracene by plant cell under sterile conditions. In: Metabolism of chemical pollution of the biosphere in plants. Tbilisi: Metsniereba: 92-98.

Devdariani TV 1988. Biotransformation of carcinogenic polycyclic aromatic hydrocarbons in plants. In: Biotransformation of xenobiotics in plants. Tbilisi: Metsniereba: 79-162.

Durmishidze SV, Devdariani TV, Kavtaradze LK and Miminoshvili TV 1979. The splitting of the "B" and "C" of aromatic rings of BP by plants in sterile conditions. In: Metabolism of chemical contaminants of the biosphere in plants. Tbilisi: Metsniereba: 121-127.

Durmishidze SV, Kavtaradze LK and Devdariani TV 1979a. On the selection and identification of certain products of enzymatic oxidation 7,10-C14-benzo(a)pyrene in plants. In: Metabolism of chemical pollution of the biosphere in plants. Tbilisi: Metsniereba: 99-108.

Glass DJ 1999. Current market trends in phytoremediation. Intl. J. Phitoremediation 1: 1-8.

Gordeziani M, Khatisashvili G, Ananiashvili T, Varazashvili T, Kurashvili M, Kvesitadze G and Tkhelidze P 1999. Energetic significance of plant monooxygenase individual components participating in xenobiotics degradation. Int. Biodeterioration \& Biodegredation 44: 49-54.

Harms H 1975. Metabolisierung von Benso(a)pyren in pflarzlichen Zellsuspensionkulturen and Weizenkeimpflanzen. Landbauforsch Vö lkenrode 25: 83-90.

Harms H, Dehnen W and Mönch W 1977. Benzo[a]pyrene metabolites formed by plant cells. Z. Naturforsch: pp. 321-326.

Khatisashvili G, Gordeziani M, Kvesitadze G and Korte F 1997. Plant monooxygenases: Participation in xenobiotic oxidation. Ecotoxicology and Environmental Safety 36: 118-122.

Kiselev PA, Bovdej NA and Schwartz D 2008. Polymorphism of the monooxygenase system and its role in the metabolic activation of benzo(a)pyrene. Xenobiotics and living systems. Proceedings of the III International Conference on 22-24 October - Minsk: BSU publishing center: pp. 58-60.

Korte F, Kvesitadze G, Ugrekhelidze D, Gordeziani M, Khatisashvili G, Buadze O, Zaalishvili G and Coulston F 2000. Organic toxicants and plants. Ecotoxicology and Environmental Safety 47: 1-26.

Kvesitadze GI, Hatisashvili GA, Sadunishvili TA and Evstigneeva ZG 2005. The metabolism of anthropogenic toxicants in higher plants. - Moscow: Nauka: pp. 199.

OND-86 2005. The method of calculation of average concentrations of harmful substances discharged to the atmosphere over a long period of time (Supplement to the OND-86). Saint-Petersburg: MSHO n.a. A.I.Voeykova: pp. 15.

OND-86. 1987. Methods of calculating the concentrations of harmful substances from enterprises' emissions in the atmosphere. Gidrometeoizdat: pp. 92.

Salt DE, Smith RD and Raskin J 1998. Phytoremediation. Annu. Rev. Plant Physiol. Plant Mol.Biol. 49: 643668.

Sandermann H 1994 Jr.: Higher plant metabolism of xenobiotics: The 'Green Liver' concept. Pharmacogenetics 4: 225-241.

Ugrehelidze DSh 1976. The metabolism of exogenous alkanes and aromatic hydrocarbons in plants. -Tbilisi: Metsniereba: 223.

(Manuscript received on 1 October, 2012; revised on 3 April, 2013) 